\title{
劇症肝炎における血液凝固能の意義に 関する実験的・臨床的検討*
}

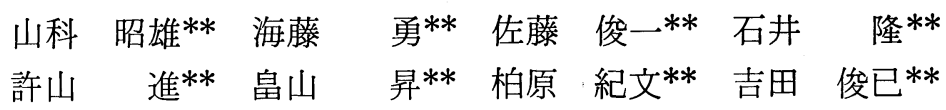

Key words : fulminant hegatitis, blood coagulation, MHV-2

hepatitis, carbon index as pagocytic activity, DIC

\section{I. 研究目的}

最近，劇症肝炎之血管内血液凝固（DIC）の 合併が注目され，DIC の 1 所見として網内系 で生成される血液凝固第V四因子の減少が重視さ れている.

われわれは劇症肝炎における血液凝固能の意 義を実験的 - 臨床的に検討し，実験的には，肝 炎の進展過程における血液凝固諸因子と網内系 機能との関連も検討した。

\section{II. 方 法}

劇症肝炎 9 例, 急性肝炎34例について hepaplastintest (HPT), thrombotest (TT), prothrombintime (PT), 血液凝固第 $\mathbb{I}, V, V I I$, VIII， IX，X因子を測定した。また，実験的劇症 肝炎として MHV-2 肝炎マウス54匹を作成し， 経時的に血液凝固第 II , V, VII, VIII, IX, X因 子ならびに網内系機能を示す墨汁指数 (C. I.) を測定した。

血液凝固諸因子は Dade 社製凝固因子測定試 薬の第 $\mathbb{I} ， \mathrm{~V} ， \mathrm{VII}, \mathrm{VII} ， \mathbb{X} ， \mathrm{X}$ 因子欠乏基質血 漿を用いた．C.I. はペリカンインク $0.1 \mathrm{~m} l / 10 \mathrm{~g}$ B.W. を尾静脈より静注し, 静注後 5 分と 25 分 の墨汁濃度を吸光度值から算出した。

\section{III. 成 績}

\section{1. 臨床成縕}

a. 血液疑固試験の検查成績

健常者においては各血液凝固試験の平均値士

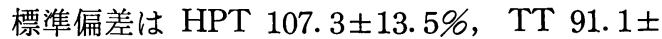

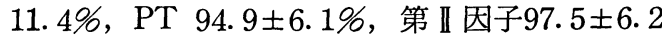
$\%$ ，第 V 因子96. 3土5.5\%，第 VII因子94. $3 \pm 8.1$ $\%$ ，第VIII因子 $101.9 \pm 9.1 \%$ ，第 IX因子 $91.6 \pm$ $9.8 \%$ ，第X因子 $95.9 \pm 8.2 \%$ あった.

劇症肝炎では, HPT $12.7 \pm 7.3 \%$, TT 11.4 $\pm 6.7 \% ，$ PT $22.8 \pm 13.0 \%$ ，第 II 因子 20.2 $\pm 14.0 \%$ ，第 V 因子 $28.9 \pm 21.0 \%$ ，第VII因子 $15.7 \pm 9.7 \%$ ，第 $\mathrm{XX}$ 因子 $30.4 \pm 15.4 \%$ ，第 X因 子26. $8 \pm 16.4 \%$ と著明に減少した。第VII因子は $300.1 \pm 92.8 \%$ と著明に増加したが，減少する 例むみられた。

急性肝炎では TT $70.6 \pm 16.6 \%$ ，第 XX因子 65. $0 \pm 21.1 \%$ と減少したが，HPT，PT および 第 II，V，VII，X因子はほとんど正常域にあっ た．第V四因子は $219.3 \pm 87.7 \%$ 之著明に増加し た.

\section{b. 急性肝炎の経過と各血液凝固試験との関} 連

急性肝炎を S-GOT, S-GPT の経過より A, B， C, D の 4 群に分けて検討した. A 群は SGOT, S-GPT が発症後 3 週以内に，B群は 3 〜 週，C群は 8 週後に正常化した例で，D群 は劇症化例を示す. 図 1 に示すごとくS-GOT,

* Experimental and clinical studies on blood coagulation in fulminant hepatitis. (The 5th Congress of the Japanese Society on Thrombosis and Hemostasis, Nov. 19, 1976).

** 岩手医科大学第一内科 (干 020 盛岡市内丸19-1), Akio YAMASHINA, Isamu KAITO, Syunichi SATO, Takashi ISHII, Susumu MOTOYAMA, Noboru HATAKEYAMA Toshihumi KASHIWABARA and Toshimi YOSHIDA : The 1st Department of Internal Medicine, Iwate Medical University, Iwate, Japan. 

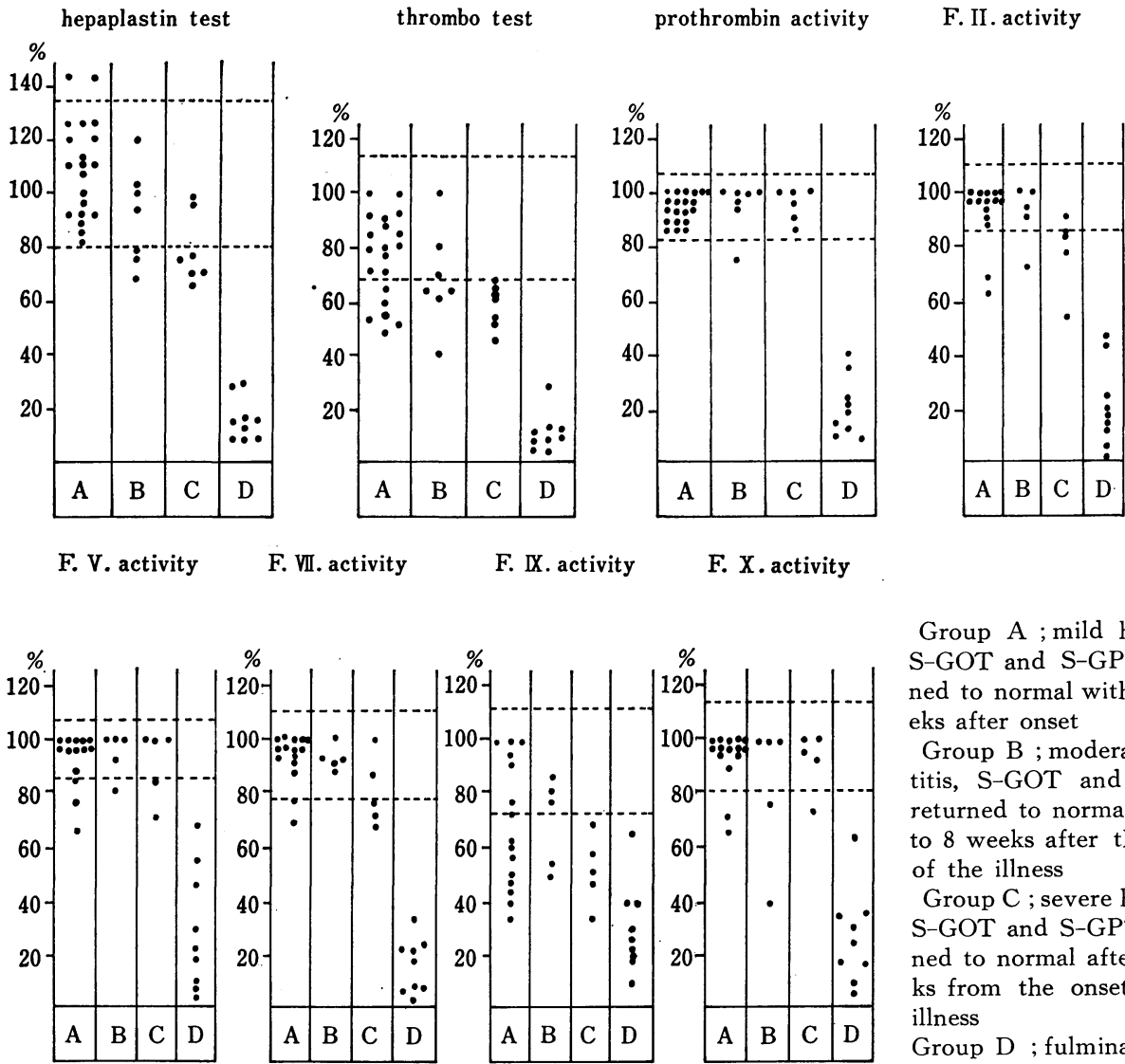

Group A ; mild hepatitis, S-GOT and S-GPT returned to normal within 3 we eks after onset

Group B ; moderate hepatitis, S-GOT and S-GPT returned to normal from 3 to 8 weeks after the onset of the illness

Group C ; severe hepatitis, S-GOT and S-GPT returned to normal after 8 wee ks from the onset of the illness

Group D ; fulminant

Fig. 1 Acivities of HPT, TT, PT and blood coagulation factors in different stages of acute hepatitis

S-GPT の正常化が遷延，すなわち肝炎の重症 度と平行して $\mathrm{HPT}, \mathrm{TT}, \mathrm{PT}$ および各血液凝 固因子は漸次減少し，D群では激減した。

さらに個々の血液凝固活性をみると $\mathrm{A}$ 群では TT と第 $\mathbb{X}$ 因子，B群では HPT，TT，第 XX因 子，C群では HPT，TT，第 II，VII，IX因子， $\mathrm{D}$ 群ではさらに $\mathrm{PT}$ ，第 $\mathrm{V} ， \mathrm{X}$ 因子の減少むみ られた。

\section{c. 急性肝资の予後と血液疑固試験との関連}

表 1 に示すように HPT，TT，PT および第 II ，V，VII，IX，X因子が70\%以上では軽快例 が大部分を占め，70〜 40\%では遷延および劇症 化が増加し，40\%以下ではほとんどが劇症肝炎 例であった。

\section{d. HPT, TT および PT と急性肝咨予後} との関連

肝炎の予後をスクリーニングテストで知るに は日常用いられている HPT, TT, PT のそれ
ぞれをあわせ測定するととに意義がある．すな わち，表 2 に示すごとく, HPT, TT, PT の 3 者が正常域あるいは TT のみが減少する場合は 予後は良く27例中 25 例軽快するが， HPT，TT の両者がとあに健常者に比し減少する場合は 7 例中 5 例が遷延，HPT，TT，PT の 3 者がとも に減少する場合は予後はきわめて悪く, 全例劇 症化を示した。

\section{2. 実験成績}

\section{a. 肝組織像の変化}

MHV-2 接種後 48 時間より単細胞壊死, 单状 壊死が，60～84時間にはびまん性肝壊死を認め た。

\section{b. 血液疑固諸因子の消長}

健常マウスにおいては各血液凝固因子の平均 值土標準偏差は 第 II 因子 90.6 $59.2 \%$ ，第 V 因 子95. $0 \pm 7.9 \%$ ，第 VII因子 $94.8 \pm 7.7 \%$ ，第V四因 子95.2 $26.7 \%$ ，第 IX因子 $91.6 \pm 4.7 \%$ ，第 X因 
Table 1 Relationship between prognoses of 43 cases with acute hepatitis and blood coagulation tests

\begin{tabular}{|c|c|c|c|c|c|c|c|c|c|c|c|c|}
\hline & \multicolumn{12}{|c|}{ blood coagulation activities } \\
\hline & \multicolumn{4}{|c|}{$>70 \%$} & \multicolumn{4}{|c|}{$70 \sim 40 \%$} & \multicolumn{4}{|c|}{$<40 \%$} \\
\hline & & improved & d persistent & fulminant & & improved & $\mathrm{d}$ persistent & fulminant & & improved & $\mathrm{d}$ persistent & fulminant \\
\hline H P T & 31 & 27 & 4 & 0 & 3 & 0 & 3 & 0 & 9 & 0 & 0 & 9 \\
\hline $\mathrm{T} \mathrm{T}$ & 15 & 15 & 0 & 0 & 19 & 12 & 7 & 0 & 9 & 0 & 0 & 9 \\
\hline $\mathrm{P} \quad \mathrm{T}$ & 34 & 27 & 7 & 0 & 0 & 0 & 0 & 0 & 9 & 0 & 0 & 9 \\
\hline F. II & 22 & 18 & 4 & 0 & 5 & 2 & 1 & 2 & 7 & 0 & 0 & 7 \\
\hline F. V & 23 & 19 & 4 & 0 & 5 & 1 & 1 & 3 & 6 & 0 & 0 & 6 \\
\hline F. VII & 22 & 19 & 3 & 0 & 3 & 1 & 2 & 0 & 9 & 0 & 0 & 9 \\
\hline F. IX & 10 & 10 & 0 & 0 & 14 & 9 & 4 & 1 & 10 & 1 & 1 & 8 \\
\hline F. $\mathrm{X}$ & 22 & 18 & 4 & 0 & 4 & 2 & 1 & 1 & 8 & 0 & 0 & 8 \\
\hline
\end{tabular}

子94. $2 \pm 5.9 \%$ あった。

MHV-2 肝炎マウスでは, MHV-2 接種後 6 時間では第壮因子を除くほとんどの血液凝固因 子は正常域にあるが，第VIII因子は $106.0 \pm 15.6$ \%とやや増加し，12時間ではさらに122.8土3.9 \%と著明に増加した. 18 時間では逆に $66.5 \pm$ 19.4\%と減少した。一方, 第 II, V, VII, IX, X因子は $6 ， 12$ 時間に比しやや減少した。ま た，第VII因子は24時間で $66.5 \pm 16.5 \% ， 30$ 時間 で56. $3 \pm 6.2 \% ， 36$ 時間で57. $3 \pm 5.4 \%$ と減少し た. 第 II， V， IX，X因子は 24 36 時間では 52.3 80.0\%と減少した。さらに第VII因子は 48 時間で $41.7 \pm 9.7 \% ， 72$ 時間で $30.7 \pm 16.7 \%$, 84 時間では $22.7 \pm 8.4 \%$ と激減し，第 II, V, VII，IX，X因子屯同様に48～84時間では14.7〜 66. $0 \%$ と減少した.

\section{c. 網内系機能の消長}

健常マウスにおいては C. I. の平均值士標準 偏差は $54.8 \pm 8.5$ であった。

MHV-2 肝炎マウスでは, MHV-2 接種後 6 時間では35. $3 \pm 6.1 ， 24$ 時間では32.6士2.2，36 時間では $36.9 \pm 7.9$ とそれぞれ減少（網内系機 能六進）した。 48 時間では減少していた C. I. は逆に59.9土11.0と健常マウスに比し増加し, 以後漸次増加を示した。ことに60時間では72.7 $\pm 10.3 ， 72$ 時間では $84.4 \pm 15.6 ， 84$ 時間では $90.6 \pm 12.2$ と著明な増加（網内系機能低下）を 示した，すなわち，第VII因子活性と網内系機能

(墨汁指数) とは密接な関連を有する. 図 2 に
Table 2 Blood coagulation tests in acute hepatitis

\begin{tabular}{|c|c|c|c|}
\hline & $\begin{array}{l}\text { improv } \\
\text { ed(27) }\end{array}$ & $\begin{array}{l}\text { persist } \\
\text { ent }(7)\end{array}$ & $\begin{array}{l}\text { fulmin } \\
\operatorname{art}(9)\end{array}$ \\
\hline $\begin{array}{l}\text { Three test of HPT,TT\&P } \\
\text { T are within normal range }\end{array}$ & 14 & 0 & 0 \\
\hline $\begin{array}{l}\text { One test of HPT,TT \& } \\
\text { PT decreases }\end{array}$ & 11 & 2 & 0 \\
\hline $\begin{array}{r}\text { Both tests of HPT\&TT } \\
\text { decrease }\end{array}$ & 2 & 5 & 0 \\
\hline " $\quad$ HPT\&PT & 0 & 0 & 0 \\
\hline " $\quad \underset{\prime \prime}{\mathrm{TT} \& \mathrm{PT}}$ & 0 & 0 & 0 \\
\hline $\begin{array}{l}\text { Three test of HPT, TT } \\
\& \text { PT decrease }\end{array}$ & 0 & 0 & 9 \\
\hline
\end{tabular}

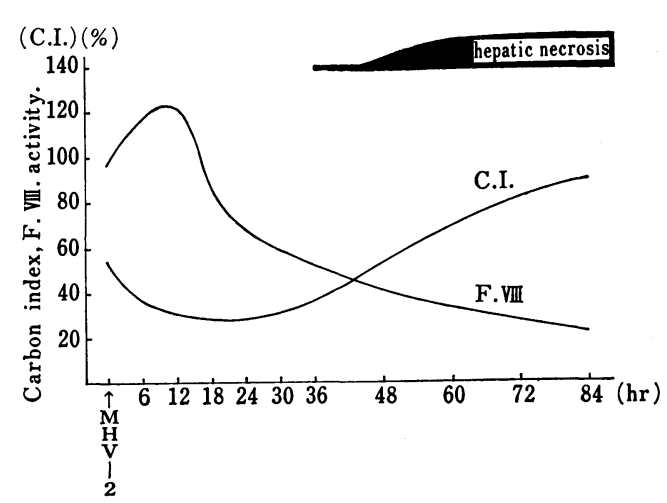

Table 2 Relationship letween F. VIII activity and carbon index as pagocytic activity

示すように, MHV-2 接種後, 第VIII因子は初期 に増加し, 肝壊死の進展とともに減少した。 乙 の変動は他の第 $\mathbb{I}, \mathrm{V}, \mathrm{VII}, \mathbb{X}, \mathrm{X}$ 因子の変動 と異なった。 C. I. は初期に減少（網内系機能 穴進）し, 肝壊死の進展とともに増加（網内系 機能低下）した. 


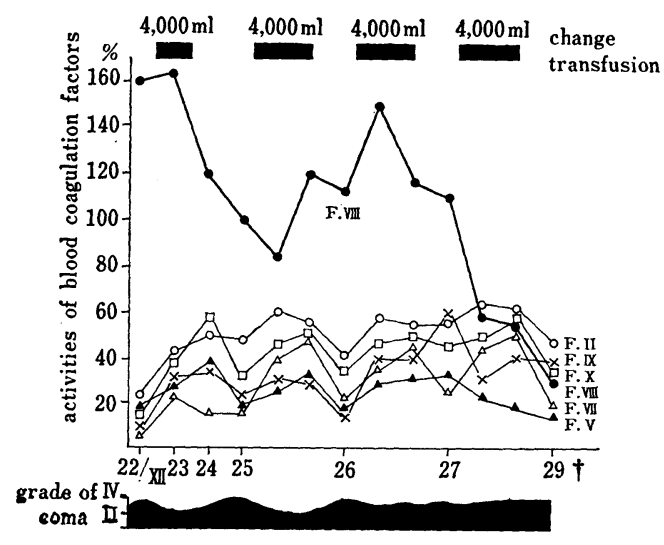

Case 1.20 y. o. female

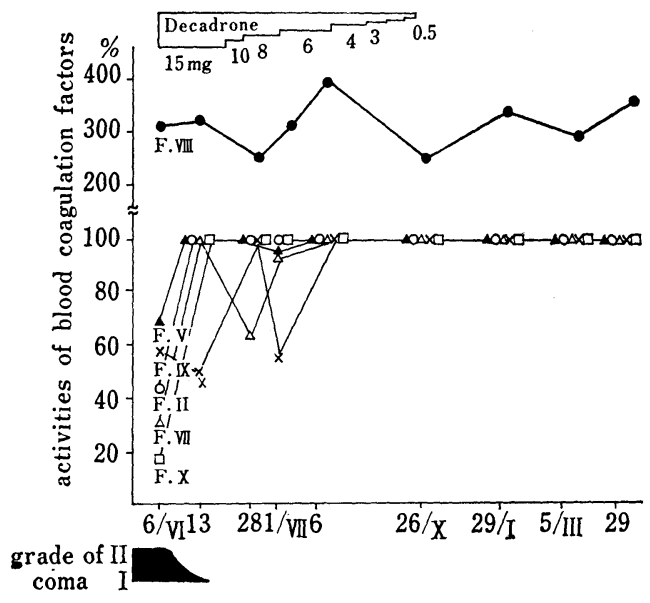

Case 2. 45 y. o. male

Fig. 3 Clinial course \& blood coagulation tests in fulminant hepatitis

\section{3. 症例検討}

症例 $1 ， 2$ を図 3 に示した。

症例 1 は20歳, 女子, 劇症肝炎である. 初診 時第 II，V，VII， X，X因子は $30 \%$ 以下と著明 に減少し，第VIII因子は $160 \%$ とむしろ増加して いた。第训因子を除く各血液凝固因子は交換輸 血施行中も著明な減少を持続した。第V四因子は 他の血液凝固因子と異なり第 1 病日より 5 日間 增加し，第 6 病日より減少し始め，第 7 病日は $30 \%$ と激減し, 間あなく死亡した。

このように，增加せる第V四因子が経過ととも に異常減少する症例の予後はきわめて不良であ る.

症例 2 は45歳, 女子, 亜急性肝炎である. 初 診時出血傾向著明で第 $\mathbb{I}, V, V I I, ~ I X, X$ 因子 は中等度～著しく減少し, 第VII因子は $316 \%$ 之 著明に增加していた。 ての症例む予後不良之思 われたが，デキサメサゾン多量投与により 1 週 間後には第V四因子を除く各血液凝固因子は急激 に増加し，出血傾向も全く認められなくなり， 3 週間後にはほとんどが正常域に達した。第VIII 因子の変動は前例之違い，大きな変化むなく増 加值を維持し, かつ活性の異常減少屯なかっ た.

このように，第V四因子が高值を持続するすの または異常減少をみないものは軽快する傾向に ある。

\section{IV. 考案}

肝実質細胞では第VII因子を除いて第 II V, VII， IX，X因子など多くの血液凝固因子が生成 される(1)2).したがって肝細胞障害時にはこれら の血液凝固因子活性の異常が生じ，肝細胞障害 の指標として, 個々の血液凝固因子およびスク リーニング検查すなわち HPT, TT, PT が用 いられる。

劇症肝炎を含めての急性肝炎の経過, 予後に おける血液凝固活性の変動について, Koller ${ }^{3)}$, Colombi i) は各血液凝固活性之肝炎の重症度之 はよく一致したと述べている.

われわれの臨床成績でも HPT, TT, PT お よび第 II，V， VII，IX，X因子は肝炎の重症度 とよく平行して減少した。ささらに，MHV-2 肝 炎マウスにおいても第 II, V, VII, IX, X因子 は肝炎の進展とともに減少した。 この成績は臨 床成績とほぼ一致するあのと考えられる。

HPT, TT, PT および第 II, V, VII, IX, X 因子は劇症肝炎で著明に減少するが，網内系で 生成される第V(I因子 ${ }^{5)}$ は一般に增加する ${ }^{3(6) 7)}$. われわれの成績でも同様であった。

さらに，Koller ${ }^{3)}$ は DIC を伴った劇症肝炎 では第林因子は逆に減少すると述べている.

われわれの動物実験です MHV-2 接種後第 VI因子は初期に増加し，肝壊死の進展とともに 
減少した.ささら第VIII因子は網内系機能の変動 ，すなわち初期に立進し，肝買死の進展ととむ に低下, とよく平行して変動した.

\section{V 結 語}

(1) 劇症肝炎では HPT, TT, PT および第 II，V， VII，IX，X因子は多くは著明な減少を み, 各試験の測定は予後の判定に有用である. 第V四因子は初期に増加し，末期に減少した。乙 の消長は肝炎の経過と密接な関連をもって変動 した。

(2) $\mathrm{MHV-2}$ 肝炎マウスでは第 II，V， VII， VIII, IX，X因子のうち，第 VIII 因子の み初期に 増加し, 肝炎の進展ととあに減少した。乙の消 長は網内系機能と密接な関連をもって変動し た。

\section{文献}

1) Olson, J. P. et al.: Synthesis of clotting factors by the isolated perfused rat liver. J. Clin. Invest., 45; 690, 1966.

2) Straub, P. W.: A study of fibrinogen production by human liver slices in vitro by an immunoprecipitin method. J. Clin. Invest., $42 ; 130,1963$.

3) Koller, F.: Theory and experience behind the use of coagulation tests in diagnosis and prognosis of liver disease. Scand. J. Gastroent., Suppl., 19; 51, 1973.

4) Colombi, A.: Early diagnosis of fatal hepatitis. Digestion, 3; 129, 1970.

5) Webster, W. P. et al.: Plasma factor VIII synthesis, and control as revealed by canine organ transplantation. Am. J. Physiol., $220 ; 1147,1971$.

6) Rapaport, S. I. et al.: Plasma clotting factors in chronic hepatocellular disease. New Eng. J. Med., 263; 278, 1960.

7) Straub, P. W. et al.: Erhöhung des antihämophilen Globulins (Faktor VWII) bei letaler lebernekrose. Schweiz. Med. Wochen., 96 ; 1199, 1966.

\section{$<$ ABSTRACT $>$}

\section{Experimental and clinical studies on blood coagulation in fulminant hepatitis.}

by

Akio YAMASHINA, Isamu KAITO, Syunichi SATO, Takashi ISHII, Susumu MOTOY. AMA, Noboru HATAKEYAMA, Toshifumi KASHIWABARA and Toshimi YOSHIDA from

The 1st Department of Internal Medicine, Iwate Medical University, Iwate, Japan.

Hepaplastintest, thrombotest, prothrombin time and blood coagulation factors II, V, VII, VIII, IX and $\mathrm{X}$ were measured in 9 cases with fulminant hepatitis, in 34 cases with acute hepatitis and in mice with MHV-2 hepatitis. Also carbon index as pagocytic activity was measured in mice with MHV-2 hepatitis. The following results were obtained.

1) The activities of the blood coagulation except for factor VIII showed a decrease in fulminant hepatitis and in acute stage of acute hepatitis as compared to healthy subjects, especially in fulminant hepatitis.

2) In acute hepatitis including fulminant hepatitis, there was a correlation between the decrease of the activities of blood coagulation except for factor VIII and severity of the disease.

3) In mice with MHV-2 hepatitis, the activities of the blood coagulation except for factor VIII decreased with the progression of hepatic necrosis. But the activities of factor VIII increased in early stage, and decreased in terminal stage of MHV-2 hepatitis with parallel to the pagocytic activity.

Therefore, it is believed that the determination of blood coagulation tests in hepatitis is useful to determine the diagnosis and prognosis of the diseases, and that the changes of factor VIII in MHV-2 hepatitis are closely related to the function of RES. 